\title{
The Role of Endotoxins in Induced Ruminal Acidosis in Calves
}

\author{
By S. Aiumlamai, H. Kindahl, G. Fredriksson, L.-E. Edqvist, L. Kulander and Ö. Eriksson
}

Department of Obstetrics and Gynaecology and Department of Clinical Chemistry, Faculty of Veterinary Medicine, Swedish University of Agricultural Sciences, Department of Medical and Physiological Chemistry, Biomedical Centre and Department of Clinical Chemistry, University Hospital, University of Uppsala, Uppsala, Sweden.

\begin{abstract}
Aiumlamai, S., H. Kindahl, G. Fredriksson, L.-E. Edqvist, L. Kulander and Ö. Eriksson: The role of endotoxins in induced ruminal acidosis in calves. Acta vet. scand. 1992, 33. 117-127. - Experimentally induced ruminal acidosis was carried out in 4 calves to investigate the possibility of resorption of endotoxins from Gram negative bacteria originating from the gastro-intestinal tract. The ruminal acidosis was induced by overfeeding of oats and the effect was evaluated by clinical and blood biochemical changes. Blood samples were collected every $2 \mathrm{~h}$ for $60 \mathrm{~h}$ before and after experimental feeding. The animals showed signs of ruminal acidosis and also the clinical and blood biochemical changes were similar to those seen after experimental endotoxaemia. However, although being less dramatic the changes in many relevant parameters such as an increase in prostaglandin $\mathrm{F}$ metabolite levels, body temperature, endotoxins and a decrease in iron indicate that an endotoxaemic state had occurred. The results of the present study show that ruminal acidosis/stasis is linked to resorption of endotoxins from the gastro-intestinal tract causing endotoxaemia/endotoxicosis.
\end{abstract}

overfeeding; prostaglandin; blood biochemical parameters; calf.

\section{Introduction}

It is wellknown that overfeeding of ruminants with feed high in carbohydrate such as grain, leads to a change in the ruminal flora (Blood \& Radostits, 1989). Already in a few hours after grain engorgement the ruminal microflora changes from predominantly Gram-negative organisms to predominantly Gram-positive lactic acid producing bacteria (Hungate et al. 1952). The subsequent accumulation of lactate in the rumen results in a marked decrease in ruminal $\mathrm{pH}$ leading to acidosis which is an important feature of the syndrome of overfeeding in ruminants.
Dying and disintegrating Gram-negative bacteria during acidosis are a potential source of endotoxin. A marked increase in the concentration of endotoxin in the rumen follows upon grain engorgement (Nagaraja et al. 1978a). Free endotoxin in ruminal fluid of normal cattle was demonstrated by death of mice injected intraperitoneally with cell-free fraction of rumen fluid (Nagaraja et al. 1978b) and calves injected intravenously exhibited clinical signs and pathophysiological changes similar to those seen in endotoxin shock (Nagaraja et al. 1979).

Endotoxins are present also in the natural 
environment and stem from growth of Gramnegative bacteria on plants and other sources of animal feed (Lindgren et al. 1988). It has been found that normally used fodder e.g. for swine and goats contained up to 12.5 and $10.6 \mathrm{mg} / \mathrm{kg}$ of endotoxin, respectively (Rylander, personal communication). The endotoxin load of cattle combining "exogenous" (endotoxin in feed) and "endogenous" (rumen) endotoxins can potentially play a role in complex disease syndromes such as e.g. ruminal acidosis, paresis puerperalis and laminitis.

Microlesions of rumen papillae of lambs as well as rumenitis in calves occur upon the feeding of grain diets (Kay et al. 1969, McManus et al. 1977). Through these lesions endotoxins might be resorbed to the blood circulation and cause subsequent pathophysiological effects. Dougherty et al. (1975a) detected endotoxin in the blood circulation by the limulus amaebocyte lysate (LAL) test in cattle and sheep after induced grain engorgement. Endotoxin was also found in blood of horses with spontaneous occurring gastrointestinal strangulation/obstruction and septicemia diseases by the LAL test (Fessler et al. 1989). In contrast the LAL test did not detect endotoxin in experimentally induced rumen acidosis in cattle (Andersen \& Jarl $\phi v$ 1990). The clearance of endotoxin from the blood circulation by the reticuloendothelial system is both rapid and efficient. Even though the levels of endotoxin cannot be detected in the blood circulation, the cascade of biological mediators will continue after endotoxin challenge and these compounds can remain in the circulation for a longer time period. Therefore, measurement of mediators of endotoxin such as tumour necrosis factor (TNF)/cachectin, interleukin1 (IL-1) and arachidonic acid metabolites might be better indicators of endotoxaemia
(Morrison \& Ryan 1987, Aiumlamai et al. 1990). In addition, more non-specific changes in blood biochemical parameters can be related to the endotoxaemia and used as markers of endotoxaemia (van Miert 1985, 1987, Aiumlamai et al. 1990, Aiumlamai \& Kindahl 1990).

In ruminal acidosis, some pathophysiological changes were similar to those found in endotoxaemia (Dougherty et al. 1975b, Andersen \& Jarl $\varnothing v$ 1990). However, proofs for the involvement of endotoxin originating from the alimentary tract in the lactic acidosis syndrome are inconclusive. The present study was carried out to demonstrate that the ruminal acidosis disease complex, induced by overfeeding with high concentrate, involves engagement of endotoxins from the alimentary tract. Clinical and blood biochemical parameters were used as indicators to clarify the exposure of endotoxin, and the LAL test was employed to determine the endotoxin concentrations in the blood circulation.

\section{Materials and methods}

\section{Animals and feeding}

Four female calves (A, B, C, D), 2 Swedish Red and White and 2 Swedish Friesian breed, aged 5 months, weighing 82 to $99 \mathrm{~kg}$, were used. They were kept separated and fed with hay and water ad libitum and a low amount of crushed oats, $0.1 \mathrm{~kg} /$ day, starting from 1 month before the experiment. At the start of the experiment, each calf was offered $5 \mathrm{~kg}$ of oats as well as hay and water ad libitum. After $24 \mathrm{~h}$ the remainder of the oats was removed and weighed.

\section{Blood sampling}

Jugular vein blood samples were obtained every $2 \mathrm{~h}$ for $60 \mathrm{~h}$ before and after feeding the high ratio of oats. Five $\mathrm{ml}$ of jugular vein 
blood was withdrawn into heparinized Vacutainer tubes (Becton \& Dickinson, England) and immediately centrifuged. Plasma was removed and stored at $-20^{\circ} \mathrm{C}$ until hormone analysis (15-ketodihydroprostaglan$\operatorname{din}(\mathrm{PG}) \mathrm{F}_{2 \alpha}$; abbreviated as PG in the text).

Ten $\mathrm{ml}$ of blood was collected under sterile precautions into plain Vacutainer tubes (Becton \& Dickinson) and centrifuged within 40 min after collection (30 min elapsed before centrifugation). Two $\mathrm{ml}$ of serum was transferred to another plain Vacutainer tube, and special care was taken to avoid contamination by endotoxins from the environment. The remainder of the serum $(3-4 \mathrm{ml})$ was transferred to a plastic tube. The samples were stored at $-20^{\circ} \mathrm{C}$ and subsequently utilised for endotoxin analysis (glass plain tubes) and for calcium $(\mathrm{Ca})$, zinc $(\mathrm{Zn})$, iron $(\mathrm{Fe})$, bile acids (BA), glutamate dehydrogenase $(\mathrm{GLDH})$, sodium $(\mathrm{Na})$ and potassium $(\mathrm{K})$ (plastic tubes).

Five $\mathrm{ml}$ of blood was withdrawn into EDTA Vacutainer tubes (Becton \& Dickinson) and immediately analysed for total white blood cell number (WBC). Differential counts were performed from blood smears.

\section{Analytical methods}

15-Ketodihydro-PGF $2 \alpha$ was analysed by radioimmunoassay (Kindahl et al. 1976, Granström \& Kindahl 1982). The detection limit of the assay was $30 \mathrm{pmol} / \mathrm{l}$ and the intraassay coefficient of variation was $6 \%$ (mean value $170 \mathrm{pmol} / \mathrm{l}$ ). All samples were analysed in the same assay.

Endotoxin (ET) quantification was performed with a modified LAL method using chromogenic substrate as described by Friberger (1985). The incubation time, $25 \mathrm{~min}$, yielded a detection limit of $5 \mathrm{ng} / \mathrm{l}$. The intraassay coefficient of variation was $12.5 \%$ (mean value $20.5 \mathrm{ng} / \mathrm{l}$ ).
Serum $\mathrm{Ca}$ and $\mathrm{Zn}$ were determined in an atomic absorption spectrophotometer (Perkin-Elmer, model 603, Connecticut, USA) according to Trudeau \& Freier (1967) and Parker et al. (1967), respectively. The interassay coefficient of variation was $1.3 \%$ (mean value $2.47 \mathrm{mmol} / \mathrm{l}$ ) and $10.3 \%$ (mean value $13.9 \mu \mathrm{mol} / \mathrm{l})$, respectively.

Serum Fe was determined by Guanidine/FerroZine $^{\mathrm{R}}$ method without deproteinization (Iron FZ test, no.0710598, Roche Diagnostica, Basel, Switzerland) according to Eisenwiener et al. (1979). The inter-assay coefficient of variation was $3.1 \%$ (mean value 24.6 umol/1).

Serum bile acids were analysed by a colourimetric method, determining total $3 \alpha-$ hydroxy bile acids in serum (Enzabile ${ }^{\mathrm{R}}$ kit, Nyegaard, Norway) according to Mashige et al. (1981). The inter-assay coefficient of variation was $5.7 \%$ (mean value $28.9 \mu \mathrm{mol} / \mathrm{l}$ ).

Serum GLDH was determined by a standard method according to the recommendations of the German Society for Clinical Chemistry (Z. Klin. Chem. Klin. Biochem. 12, p. 391, 1974) (GLDH One-vial test, no.0712124, Roche Diagnostica, Basel, Switzerland). The inter-assay coefficient of variation was $6.3 \%$ (mean value $223 \mathrm{nkat} / \mathrm{l}$ ).

Serum $\mathrm{Na}$ and $\mathrm{K}$ were determined by using an Orion 1020 ion selective membrane (Orion Research Inc., MA, USA) according to Ruff (1982). The inter-assay coefficient of variation was $1.0 \%$ (mean value 158.8 $\mathrm{mmol} / \mathrm{l}$ ) and $0.9 \%$ (mean value $6.7 \mu \mathrm{mol} / \mathrm{l}$ ), respectively.

The total WBC was counted in a Sysmex F800 electronic counter (Toa Medical Co., Japan) and the inter-assay coefficient of variation was $1.6 \%$ (mean value $19.0 \times 10^{9}$ cells/l). Quicklyzer QLY-200A was added to lyse the red blood cells. Differential counting of 200 cells was performed in a microscope, 
after staining with May-Grünewalds solution followed with Giemsa solution. Differential count was simplified by dividing the cells in polymorphonuclear (neutrophil, basophil and eosinophil) (PMN) and mononuclear (monocyte, macrophage and lymphocyte) $(\mathrm{MN})$. The cell numbers are given as absolute values.

\section{Clinical examination}

Rectal body temperature (BT) was measured at each blood sampling. Frequency of rumen contractions ( $R C$ ) was recorded every $2 \mathrm{~h}$ during daytime throughout the period of study. Ruminal content was collected by suction through a stomach tube twice daily during the control period and thrice during the experimental period. The $\mathrm{pH}$ of the content was recorded both by $\mathrm{pH}$-paper and a $\mathrm{pH}$ meter.

\section{Statistical analysis}

Differences of all parameters, in every $12 \mathrm{~h}$ intervals (7.00 am - $7.00 \mathrm{pm}$ ), from individual animals, were evaluated by analysis of variance (the Statgraphics Version 4.0, STSC, Inc.) and a confidence interval test was used to compare means, separately for the control and experimental periods. This evaluation was done to define the effect of the frequency of collecting blood samples during a long period or effect of day and night on the parameters. Then, the values from the experimental period for every $12 \mathrm{~h}$ interval were compared with the values of the respective $12 \mathrm{~h}$ interval during the control period by Student's $t$ test. Two criteria were used to determine significant changes during the experimental period for the investigated parameters. First, the difference must be greater than the $95 \%$ confidence interval set by the analytical error, and second the difference must be significant when compared to the corresponding value from the control period and/or to other $12 \mathrm{~h}$ intervals during the experimental period. In addition, the normal physiological range established for healthy cattle for the parameters investigated were also used to assess the biological importance of recorded alterations. This procedure does not relate to $\mathrm{pH}, \mathrm{RC}$ and $\mathrm{BT}$, where the significance was judged from comparisons between the control periods and the variation within the experimental periods.

\section{Results}

\section{Control period}

During the control period, all animals were clinically normal. The changes of all parameters were evaluated, in each individual animal, in every $12 \mathrm{~h}$ time interval during the control period $(60 \mathrm{~h})$. Rectal body temperature during the daytime was significantly higher than during the night. The levels of $\mathrm{pH}, \mathrm{RC}, \mathrm{PG}, \mathrm{Zn}, \mathrm{Na}, \mathrm{K}$ and $\mathrm{WBC}$ were not significantly changed during the control period. The levels of endotoxin were significantly elevated in animals A and D (at 13-24 h after the control period started). Calcium decreased significantly during the long period of frequent blood sampling (animals A, C and D). The changes in Fe, GLDH and BA were inconsistent. In animal $\mathrm{D}, \mathrm{Fe}$ levels were lower than the normal reference range, GLDH activity increased significantly and BA values were recorded higher as compared to the other animals.

\section{Experimental period}

In the experimental period, the animals started to show signs of anorexia and weakness about 8 to $10 \mathrm{~h}$ after the $5 \mathrm{~kg}$ feeding. In the next day, oats was weighed and found to be $0.0,0.3,2.0$ and $0.7 \mathrm{~kg}$ for animals $\mathrm{A}, \mathrm{B}, \mathrm{C}$ and $\mathrm{D}$, respectively. The degree of weakness and discomfort increased, they laid down, the 
rumen was distended like during mild bloat and feces was of a soft consistency. The clinical signs remained until 34 to $36 \mathrm{~h}$ later. General clinical signs disappeared during the last few hours of experimental period.

Table 1 summarizes the changes of all parameters seen during the experimentally induced acidosis presented for each animal.

The $\mathrm{pH}$ of the ruminal content was significantly decreased in 3 animals (A, B \& C) from $6.76 \pm 0.13(x \pm$ S.D. $)$ to $5.11 \pm 0.39$. Animal D had a tendency to decrease. The lowest $\mathrm{pH}$ values occurred 13-24 h after feeding in all animals except animal $\mathrm{C}$, where the lowest $\mathrm{pH}$ occurred during the first $12 \mathrm{~h}$ inteval.

In all animals rectal body temperature increased significantly to $38.8-39.2^{\circ} \mathrm{C}, 13-24 \mathrm{~h}$ after feeding in all animals. In animals A, B and $\mathrm{C}$ significantly elevated body temperature remained until 48, 60 and $36 \mathrm{~h}$ after feeding, respectively. Even though BT was significantly higher during the day than at night, when the levels were compared in respective time interval the changes showed significance.

Table 1. A summary of the changes in clinical and blood biochemical parameters seen in experimentally induced acidosis in 4 calves

\begin{tabular}{|c|c|c|c|c|}
\hline Parameters & Animal A & Animal B & Animal C & Animal D \\
\hline $\mathrm{pH}$ & - & - & - & $(-)$ \\
\hline BT & + & + & + & + \\
\hline $\mathrm{RC}$ & - & - & - & 0 \\
\hline ET & 0 & $(+)$ & $(+)$ & + \\
\hline PG & $(+)$ & + & + & 0 \\
\hline $\mathrm{Ca}$ & $(-)^{a}$ & $0^{\mathrm{a}}$ & $(-)^{a}$ & $0^{\mathrm{a}}$ \\
\hline $\mathrm{Zn}$ & $0^{\mathrm{a}}$ & $-^{a}$ & $0^{\mathrm{a}}$ & $t^{b}$ \\
\hline $\mathrm{Fe}$ & $-b$ & $-b$ & $-b$ & $(+)^{\mathrm{a}}$ \\
\hline BA & $(+)$ & 0 & + & $(+)$ \\
\hline GLDH & - & - & - & - \\
\hline $\mathrm{Na}$ & 0 & 0 & 0 & 0 \\
\hline $\mathrm{K}$ & $-b$ & $0^{\mathrm{b}}$ & $0^{\mathrm{b}}$ & $-b$ \\
\hline WBC & $+^{b}$ & $t^{\mathrm{a}}$ & $(+)^{\mathrm{a}}$ & $0^{\mathrm{a}}$ \\
\hline $\mathrm{MN}$ & 0 & 0 & 0 & 0 \\
\hline PMN & $+^{b}$ & $+^{\mathrm{a}}$ & $+^{\mathrm{a}}$ & $t^{\mathrm{a}}$ \\
\hline
\end{tabular}

+ indicates significant increase $(\mathrm{p}<0.05)$, - indicates significant decrease $(\mathrm{p}<0.05)$ and 0 indicates no significant changes. ( ) indicates a tendency to increase or decrease. Superscript "a" indicates that the values are in the normal range and superscript " $b$ " indicates that the values are out of the normal range (if no superscript is given it means that no reference range exists for that parameter in cattle). The reference ranges of the parameters are used in the Department of Clinical Chemistry, Faculty of Veterinary Medicine, Swedish University of Agricultural Sciences.
$\mathrm{BT}=$ Body temperature
$\mathrm{RC}=$ Ruminal contractions
$\mathrm{BA}=$ Bile acids
$\mathrm{ET}=$ Endotoxin
$\mathrm{WBC}=$ Total white blood cell count
GLDH $=$ Glutamate dehydrogenase
$\mathrm{MN}=$ Mononuclear cells
$\mathrm{PMN}=$ Polymorphonuclear cells 
In the experimental period, frequency of ruminal contractions decreased significantly in 3 animals ( $\mathrm{A}, \mathrm{B}$ and $\mathrm{C}$ ) but animal $\mathrm{D}$ showed no change. In animals $A$ and $B$, the frequency of contractions decreased significantly $24 \mathrm{~h}$ after feeding and remained low until the study finished. In animal $\mathrm{C}$, ruminal contractions decreased $0-24 \mathrm{~h}$ after feeding. Then the contractions increased to normal frequencies and remained so until the study finished.

The endotoxin levels were significantly increased in animal D and showed a tendency to increase in animals B and C. In animal A no change of the endotoxin levels was seen.

Prostaglandin levels were significantly increased in 2 animals (B and C) 49-60 h and $37-48 \mathrm{~h}$ after feeding, respectively. Animal A had a tendency to an increase 49-60 h after feeding. No significant change was found in animal D.

Calcium levels decreased significantly in the control period as well as during the experimental period. However, the degree of decrease in experimental period was more pronounced than during the control period. Animals $\mathrm{A}$ and $\mathrm{C}$ showed a tendency to a decrease during 37-60 $\mathrm{h}$ and $49-60 \mathrm{~h}$ after feeding, respectively. There were no changes in animals B and D as compared to the control period. All the values of $\mathrm{Ca}$ in this study were in the normal range.

The levels of $\mathrm{Zn}$ decreased significantly in 1 animal (B) 49-60 $\mathrm{h}$ after feeding and increased significantly in animal D 49-60 h after feeding. No changes were recorded in animals $\mathrm{A}$ and $\mathrm{C}$.

In the control period, the levels of $\mathrm{Fe}$ in different $12 \mathrm{~h}$ intervals gave significant but inconsistent changes. However, respective comparison resulted in that, there was a significant and dramatic decrease in 3 animals
(A, B and C) $25 \mathrm{~h}$ after feeding and the values were lower than the reference values. Animal D showed a tendency to increase 13$24 \mathrm{~h}$ after feeding and then the values were within the normal range.

Bile acids showed a significant increase in animal C, 37-48 $\mathrm{h}$ after feeding followed by a tendency to increase $49-60 \mathrm{~h}$ after feeding. In animals $\mathrm{A}$ and $\mathrm{D}$, the levels of BA showed a tendency to increase 37-48 and 49-60 h after feeding, respectively.

During the control period, the levels of GLDH showed a significant decrease in animal $\mathrm{A}$ and increase in animal D. However, using all above mentioned criteria, the levels of GLDH decreased significantly in all animals during the experimental period at 25$60,13-48,13-24$ and $37-60 \mathrm{~h}$ after feeding, respectively.

The levels of $\mathrm{Na}$ did not show significant changes in none of the animals neither during control nor during experimental period. The levels of $\mathrm{K}$ during the experimental period showed a significant decrease in animals A and D.

During the experimental period, WBC significantly increased in 2 animals, $\mathrm{A}$ and $\mathrm{B}$, and showed tendency to increase in animal $\mathrm{C}$. There was no significant change in animal D. The levels of MN had no significant changes in none of the animals during the experimental period. There was a significant increase in PMN in all animals.

\section{Discussion}

The general clinical picture seen in this study accord well with what is observed in the rumen acidosis syndrome (Dirksen 1970).

During the control period, some of the parameters investigated e.g. $\mathrm{Ca}, \mathrm{Fe}, \mathrm{GLDH}$ showed significant changes. These changes are probably due to the long period and high frequency of blood collection. The effect of 
day and night on BT was pronounced and is reported previously (Andersson 1984). The levels of ET were also found elevated, which may represent the escape to the blood circulation from the intestines as has been described in the rat (Gans \& Matsumoto 1974). These effects taken together made it reasonable to compare the results of the respective time interval between the control and the experimental period.

Three of the animals behaved very similarly in most of the recorded changes both in clinical and blood chemical parameters. The 4th animal (D) however differed markedly e.g. the frequency of ruminal contractions never decreased and the response was different in the levels of the prostaglandin metabolite, zinc, iron and total white blood cells. The reason for this is not known but it can be linked to that the decrease in ruminal $\mathrm{pH}$ was small and that ruminal stasis never occurred. Animal D was obviously less affected by the experimental feeding than the other 3 animals.

The clinical and blood biochemical changes, demonstrated in this study, showed similarities to those observed after experimental endotoxaemia. It indicates that ruminal acidosis/rumenitis is linked to resorption of endotoxins from the gastro-intestinal tract causing endotoxaemia/endotoxicosis. Leukocytosis, especially the increase in number of polymorphonuclear cells, was found in all animals which accord well with what has been demonstrated after injection of low doses of endotoxin, or endotoxins contaminated biological preparations, to rabbits and sheep (Yagoda et al. 1990 a,b). When higher doses of endotoxin are injected, a pronounced leukopenia is seen which is followed by leukocytosis the next day (Fredriksson 1984, Aiumlamai \& Kindahl 1990). Several of the studied parameters discussed below sup- port the hypothesis that endotoxins are resorbed in low amounts to the blood circulation: increase in body temperature, endotoxin and prostaglandin metabolite levels as well as decrese in iron, calcium and zinc levels. Furthermore, the decrease in ruminal contractions is a clinical sign of acidosis as well as of endotoxaemia. In the present study primary hypomotility of the rumen might be caused by acidosis but then combined and complicated by the effect of endotoxins.

In this study, the endotoxin was detected in the blood circulation from all animals both during the control and experimental periods. However, only 1 of 4 animals showed a significant increase after the experimental feeding and 2 other animals showed a tendency to an increase. The LAL test used here is sensitive and relatively specific for endotoxin and can detect very low concentrations of endotoxin present (detection limit of $5 \mathrm{ng} / \mathrm{l}$ ) in blood serum (Friberger 1985, Sturk et al. 1987). However, it can give false-positive results which can be caused by contamination of collected samples and also false-negative if endotoxin is circulating as immune complexes or if phagocytic cells have cleared endotoxin from the circulation (Elin et al. 1975, Smith 1986). Detoxification of endotoxins by the liver is normally very efficient and after an injection of endotoxin, the clearance from the circulation is rapid and makes it difficult to detect in blood. After injection of high amounts of endotoxins to goats, it was not possible to detect it in the circulation despite a very frequent blood sampling (Aiumlamai et al. 1990). This makes the detection of endotoxin in blood a difficult task. In the present study, levels of endotoxin were low and did not exceed $50 \mathrm{ng} / \mathrm{l}$ after feeding. Because of the rapid half-life of endotoxin the possible presence of higher concentrations in between the blood sam- 
plings can not be ruled out. The clinical acidosis elicited here was not particularly severe so it is however likely that resorption of endotoxins from the alimentary tract was not too dramatic and consequently the levels in the circulation should not be high. Nevertheless this low continuous resorption of endotoxins can provoke severe effects and complicate the disease situation. The animals will come into a circulus vitiosus where the resorption of endotoxins can decrease the motility of the gastro-intestinal tract leading to further resorptions of endotoxins. Andersen \& Jarløv (1990) were unable to detect endotoxin in the blood plasma samples in cattle after provoking ruminal acidosis by feeding of barley. However, the clinical and clinical-chemical data especially regarding the arachidonic acid metabolites suggested that an endotoxicosis developed.

The increase in the body temperature is also a strong support for that endotoxins have been resorbed, since endotoxins are known to be strong pyrogens (Milton 1982, Dinarello 1983). Also the release of $\mathrm{PGF}_{2 \alpha}$, from the arachidonic acid cascade, judged by its main metabolite, is a very dominating endotoxin-mediated product (Fredriksson 1984, Fredriksson et al. 1985, Aiumlamai et al. 1990, Kindahl et al. 1990). Thus, this is a very reliable parameter for estimating the effect of endotoxins. The release of prostaglandin in the present study was not so pronounced as found after intravenous injection of higher doses of endotoxin which involves lysis of the corpus luteum with subsequent alterations of sexual cycles and abortion in female animals (Fredriksson et al. 1985, Kindahl et al. 1990). However, the lower amount of prostaglandin release from acidosis/overfed animals could possibly impair reproductive behaviour when it becomes involved in a circulus vitiosus situation.
The decrease of Fe levels was pronounced and below the reference range. This is also found in experimental endotoxaemia (Luthman et al. 1990, Aiumlamai \& Kindahl 1990). Iron is one of the best parameters to estimate the effect of sepsis. The decreases of $\mathrm{Ca}$ and $\mathrm{Zn}$ levels were comparatively less severe than during experimental endotoxaemia. These minor changes might be related to the low levels of endotoxins possibly resorbed to the blood circulation, which cause mild pathophysiological changes differing from injection of large doses of endotoxins. The changes in these parameters are not specific to endotoxin response but can be considered as an indicator of the effect of endotoxin. There was no changes in $\mathrm{Na} \mathrm{lev-}$ els and also the changes of $\mathrm{K}$ levels are uncertain in the present study. Lohuis et al. (1988) reported that there were no marked changes in $\mathrm{Na}$ and $\mathrm{K}$ after endotoxin injection in cows and goats but the levels increased in sheep. However, in a recent study it was demonstrated that endotoxin injection in heifers showed initially an increase and a tendency to a decrease of $\mathrm{Na}$ and K later on (Aiumlamai \& Kindahl 1990). It has also been reported that there was an immediate depression of renal $\mathrm{Na}$ and $\mathrm{K}$ excretion followed by natriuresis after endotoxin injection (Jónasson et al. 1984).

Glutamate dehydrogenase is primarily a mitochondrial enzyme and is used to assess the integrity of hepatic cells in ruminants (Mullen 1976). The decrease of GLDH activity found here indicated a lack of direct liver cell damage. This differs markedly from the changes in GLDH activity found after the intravenous injection of high doses of endotoxin which showed a dramatic increase immediately after endotoxin injection and then followed by a return to the basal activity (Aiumlamai \& Kindahl 1990). In this case, it 
indicated a disturbed liver cell integrity. We have no obvious explanation for the decrease in GLDH activity found here. The decrease in GLDH activity may indicate a disturbed hepatic blood circulation compromising the release of the enzyme to the general circulation. Bile acids showed an increase or a tendency to increase during the later part of the experimental period. This finding is different when compared to the situation following injection of high doses of endotoxin which showed an initial increase in the levels and then followed by a decrease (Aiumlamai et al. 1990, Aiumlamai \& Kindahl 1990). The differences of the profile found might be caused by low levels of endotoxins absorbed to the blood circulation. Blood concentrations of BA are dependent on a functional enterohepatic circulation. Consequently, hypomotility of the alimentary tract of dairy cows was found to decrease BA in blood (Olsson 1986). It has also been reported that bile acids play an important role in detoxification of endotoxins (Kocsár et al. 1973, Bertók 1980). However, the profiles of GLDH and BA found in this study/acidosis are interesting and require further investigation.

Interestingly, the ruminal contractions are found to decrease/stasis during the acidosis syndrome and endotoxaemia as well as in other complex diseases such as parturient paresis. It is possible that some endotoxin mediators cause the obstruction of the motility of the rumen leading to accumulation of endotoxins in the rumen. A certain amount of this could then be resorbed to the blood circulation and cause the pathophysiological changes. Thus, it is important to study the effect of ruminal stasis related to the possible role of endotoxins in complex diseases where ruminal stasis is pronounced.

The changes of the parameters demonstrated in this study were less dramatic compared to experimentally induced endotoxaemia in the same species. However, they showed significant changes in many relevant parameters such as prostaglandin, iron, body temperature and endotoxin itself which indicates the exposure of low amounts of endotoxins. They are similar to those recorded following administration of large doses of endotoxins. In addition, individual animals showed different pictures in some parameters which could depend on body condition, degree of acidosis, tolerance, defence mechanisms and levels of absorbed endotoxin to the blood circulation. In conclusion, it seems likely that the ruminal acidosis disease complex was complicated by endotoxins from the alimentary tract.

\section{Acknowledgements}

The authors would like to thank Dr. Andrzej Madej for valuable advice regarding the statistical evaluation. This study was supported by grants from the Swedish Council for Forestry and Agricultural Research. Department of Animal Breeding and Genetic is acknowledged for the kind and generous loan of animals. The Dairy Farming Promotion Organization of Thailand is gratefully acknowledged for permitting the leave of absence of $\mathrm{S}$. Aiumlamai.

\section{References}

Aiumlamai S, Fredriksson $G$, Kindahl H, Edqvist L$E$, Kulander L, Eriksson Ö: Endotoxin concentrations in the blood following intravenous injection and effect on prostaglandin $\mathrm{F}_{2 \alpha}$ release, calcium and bile acids in goats. Res. vet. Sci. 1990, 48, 190-195.

Aiumlamai $S$, Kindahl $H$ : Clinical and blood biochemical changes during induction of endotoxaemia in heifers. Acta vet. scand. 1990, 31, 501-504.

Andersen PH, Jarl $\varnothing v N$ : Investigation of the possible role of endotoxin, TXA2, PGI2, and PGE2 in experimentally induced rumen acidosis in cattle. Acta vet. scand. 1990, 31, 27-38.

Andersson $B E$ : Temperature regulation and environmental physiology. In: Swenson MJ (ed.): Dukes' Physiology of Domestic Animals.10th ed. 1984 , pp. $720-727$. 
Bertók L: Role of bile in detoxification of lipopolysaccharide. Microbiology 1980, 123, 91-93.

Blood DC, Radostits OM: Acute carbohydrate engorgement of ruminants (rumen overload). In: Veterinary Medicine 7th ed., 1989, 246-253.

Dinarello CA: Molecular mechanisms in endotoxin fever. Agents Actions 1983, 13, 470-486.

Dirksen G: Acidosis. In: Phillipson AT (ed.): Physiology and Metabolism in the Ruminant 1970 , pp. 612-629.

Dougherty RW, Coburn KS, Cook HM, Allison MJ: Preliminary study of appearance of endotoxin in circulatory system of sheep and cattle after induced grain engorgement. Amer. J. vet. Res. 1975a, 36, 831-832.

Dougherty RW, Riley JL, Baetz AL, Cook HM, Coburn KS: Physiologic studies of experimentally grain-engorged cattle and sheep. Amer. J. vet. Res. 1975b, 36, 833-835.

Eisenwiener H-G, Rietz P, Schläpfer P: Die Bestimmung des Eisens mit der Guanidiniumchlorid/Ferrozin-Methode. (Estimation of iron by Guanidinium chloride/Ferrozin method). J. clin. chem. clin. Biochem. 1979, 17, 149.

Elin J, Robinson RA, Levine AS, Wolff SM: Lack of clinical usefulness of the Limulus test in the diagnosis of endotoxemia. N. Engl. J. Med. 1975, 292, 521-524.

Fessler JF, Bottoms GD, Coppoc GL, Gimarc S, Latshaw HS, Noble JK: Plasma endotoxin concentrations in experimental and clinical equine subjects. Equine vet. J. 1989, Suppl. 7, 24-28.

Fredriksson $G$ : Some reproductive and clinical aspects of endotoxins in cows with special emphasis on the role of prostaglandins. Acta vet. scand. 1984, 25, 365-377.

Fredriksson $G$, Kindahl $H$, Edqvist L-E: Endotoxin-induced prostaglandin release and corpus luteum function in goats. Anim. reprod. Sci. 1985, 8, 109-121.

Friberger P: The design of a reliable endotoxin test. In: ten Cate JW, Büller HR, Sturk A, Levin J, (eds.): Bacterial Endotoxins: Structure, biomedical significance, and detection with the Limulus amebocyte lysate test. Alan R Liss, 1985, pp. 139-149.

Gans $H \&$ Matsumoto $K$ : Are enteric endotoxins able to escape from the intestine? Proc. Soc. Exp. Bio. Med. 1974, 147, 736-739.

Granström E, Kindahl $H$ : Radioimmunoassay of the major plasma metabolite of $\mathrm{PGF}_{2 \alpha}, 15$-keto13,14-dihydro-PGF $2 \alpha$. Methods Enzymol. 1982, 86, 320-339.
Hungate RE, Dougherty RW, Bryant MP, Cello $R$ $M$ : Microbiological and physiological changes associated with acute indigestion in sheep. Cornell Vet. 1952, 42, 423-449.

Jónasson $H$, Basu S, Andersson B, Kindahl $H$ : Renal excretion of prostaglandin metabolites, arginine vasopressin, and sodium during endotoxin and endogenous pyrogen induced fever in the goat. Acta physiol. scand. 1984, 120, 529-536.

Kay M, Fell BF, Boyne R: The relationship between the acidity of the rumen contents and rumenitis, in calves fed on barley. Res. vet. Sci. 1969, 10, 181-187.

Kindahl H, Edqvist L-E, Granström E, Bane A: The release of prostaglandin $\mathrm{F}_{2 \alpha}$ as reflected by 15-keto-13,14-dihydroprostaglandin $F_{2 \alpha}$ in the peripheral circulation during normal luteolysis in heifers. Prostaglandins 1976, 11, 871-878.

Kindahl H, Odensvik $K$, Fredriksson $G$, Cort $N$, Daels P, Hughes J, Stabenfeldt GH: Effects of endotoxins on prostaglandin biosynthesis and reproductive function in farm animals. Proc. 4th Congr. Eur. Ass. Vet. Pharmacol. \& Toxicol, Budapest, Aug. 28-Sept. 2, 1988, Simon F, Lees P, Semjén G, (eds.), 1990, pp. 205-212.

Kocsár LT, Bertók L, Várterész V: Function of bile acids in the intestinal absorption of endotoxin in rats. Annal. Immunol. Hung. 1973, Suppl. 17, 49-51.

Lindgren S, Bromander A, Pettersson K: Evaluation of silage additives using scale-model silos. Swedish J. agri. Res. 1988, 18, 41-49.

Lohuis JACM, Verheijden JHM, Burvenich C, van Miert ASJPAM: Pathophysiological effects of endotoxins in ruminants. Vet. Quart. 1988, 10, 117-125.

Luthman J, Kindahl H, Jacobsson S-O: The influence of flunixin on the response to Salmonella typhimurium endotoxin in calves. Acta vet. scand. 1990, 31, 295-300.

Mashige F, Tanaka N, Maki A, Kamei S, Yamanaka $M$ : Direct spectrophotometry of total bile acids in serum. Clin. Chem. 1981, 27, 1352-1356.

McManus WR, Lee GJ, Robinson VNE: Microlesions on rumen papillae of sheep fed diets of wheat grain. Res. vet. Sci. 1977, 22, 135-137.

Milton AS: Prostaglandins and fever. Trends in Pharmacol. Sci. 1982, 3, 490-492.

Mullen PA: The diagnosis of liver dysfunction in farm animals and horses. Vet. Rec. 1976, 99, 330-334. 
Morrison DC, Ryan JL: Endotoxins and disease mechanisms. Ann. Rev. Med. 1987, 38, 417-432.

Nagaraja TG, Bartley EE, Fina LR, Anthony HD: Relationship of rumen Gram-negative bacteria and free endotoxin to lactic acidosis in cattle. J. Anim. Sci. 1978a, 47, 1329-1337.

Nagaraja TG, Bartley EE, Fina LR, Anthony HD, Dennis SM, Bechtle RM: Quantitation of endotoxin in cell-free rumen fluid of cattle. J. Anim. Sci. 1978b, 46, 1759-1766.

Nagaraja TG, Bartley EE, Anthony HD, Leipold $H W$, Fina $L R$ : Endotoxin shock in calves from intravenous injection of rumen bacterial endotoxin. J. Anim. Sci. 1979, 49, 567-582.

Olsson $T$ : Serum bile acids in hypocalcaemic dairy cows. 6th Int. Conf. Product Dis. Farm Animals, 1986, Belfast, 20-23.

Parker MM, Humoller FL, Mahler DJ: Determination of copper and zinc in biological material. Clin. Chem. 1967, 13, 40-48.

Ruff WL: Sodium and potassium. In: Faulker WR, Mites S (eds.): Selected methods for the small clinical chemistry laboratory. 1982, 9, 341-345.

Smith BP: Understanding the role of endotoxins in Gram-negative septicemia. Vet. Med. 1986, 81, 1148-1161.

Sturk A, Janssen ME, Muylaert FR, Joop K, Thomas LLM, ten Cate JW: Endotoxin testing in blood. In: Watson S W, Levin J, Novitsky $\mathrm{T}$ J. (eds.): Detection of Bacterial Endotoxins with the Limulus Amebocyte Lysate Test. Alan R Liss, 1987, pp. 371-385.

Trudeau DL, Freier EF: Determination of calcium in urine and serum by atomic absorption spectrophotometry (AAS). Clin. Chem. 1967, 13, 101-114.

van Miert ASJPAM: Fever and associated clinical haematologic and blood biochemical changes in the goat and other animal species. Vet. Quart. $1985,7,200-216$. van Miert ASJPAM: Fever, anorexia and forestomach hypomotility in ruminants. Vet. Res. Comm. 1987, 11, 407-422.

Yagoda CR, Bylund-Fellenius $A-C$, Kindahl $H$ : Some effects of Gram-negative bacterial endotoxin and its importance as a contaminator of biological preparations. Acta vet. scand. 1990a 31, 193-206.

Yagoda CR, Bylund-Fellenius AC, Adner N, Kindahl $H$ : Biological responses of sheep treated with endotoxin-contaminated superoxide dismutase and endotoxin preparations. Acta vet. scand. 1990b, 31, 207-217.

\section{Sammanfattning}

Betydelse av endotoxiner? I. Vid inducerad våmacidos hos kalv.

Experimentellt inducerad våmacidos utfördes för att undersöka möjligheten av resorption av endotoxiner från Gram-negativa bakterier i magtarmkanalen hos kalv. Våmacidosen inducerades med överutfodring av havre och effekten utvärderades genom kliniska och blodkemiska förändringar. Blodprover samlades varannan timme i $60 \mathrm{t}$ före och efter överutfodringen. Djuren visade tecken på våmacidos och både den kliniska och blodkemiska bilden liknar den som ses efter experimentell endotoxinämi. Förändringarna vid våmasidos var förvisso icke så dramatiska men många relavanta parametrar som $t$. ex. ökning av prostaglandin $\mathrm{F}_{2 \alpha}$ metaboliter, kroppstemperatur, endotoxiner och sänkning av järnnivåer indikerade att ett endotoxinämistadium förelåg. Resultaten från denna studie visar att våmacidos/stas är förenat med en resorption av endotoxiner från mag-tarmkanalen som orsakar endotoxinæmi/endotoxikos.

(Received October 2, 1991; accepted October 11, 1991).

Reprints may be requested from: Hans Kindahl, Department of Obstetrics and Gynaecology, Swedish University of Agricultural Sciences, Box 7039, S-750 07 Uppsala, Sweden. 